\title{
Effect of catch crop and type of ploughed-in biomass on the health status of stem base and roots of spring wheat
}

\section{Oddziaływanie międzyplonów ścierniskowych i rodzaju przyoranej biomasy na zdrowotność podstawy źdźbła i korzeni pszenicy jarej}

\author{
Grzegorz Lemańczyk ${ }^{1 *}$, Edward Wilczewski ${ }^{2}$, Wojciech Węglarz ${ }^{1,3}$
}

\begin{abstract}
Summary
The aim of the study was to evaluate the effect of type of ploughed-in biomass (biomass of underground and aboveground parts; post-harvest residue biomass) of legume plants (serradella, field pea and yellow lupine) grown in stubble catch crops on health status of roots and stem base of spring wheat cultivar Nawra. The pot experiment was carried out in a greenhouse in 4 series. The wheat health status was estimated 6 weeks after sowing of wheat. There was a significant effect of catch crop on the occurrence of foot and root rot wheat diseases. Legume plants grown as a catch crops showed positive effect on the occurrence of Fusarium foot rot. Cultivation of wheat after serradella crop significantly improved the health status of roots. Type of ploughed-in biomass showed an ambiguous effect on the health of wheat. Gaeumannomyces graminis was the most common pathogen isolated from wheat roots with necrosis symptoms. Fusarium spp., Rhizoctonia spp. and Cochliobolus sativus were isolated less frequently. The fungi isolated from the stem base represented mainly Fusarium culmorum, Fusarium oxysporum and C. sativus. Definitely less frequently isolated fungi represented other Fusarium species, Rhizoctonia spp. and G. graminis.
\end{abstract}

Key words: stubble catch crop; spring wheat; roots; stem base; diseases; fungi

\section{Streszczenie}

Badania, których celem było określenie wpływu rodzaju przyoranej biomasy (biomasa części podziemnych i nadziemnych; biomasa resztek pozbiorowych) różnych gatunków roślin bobowatych (seradeli siewnej, grochu siewnego, łubinu żółtego) uprawianych w międzyplonie ścierniskowym na zdrowotność korzeni i podstawy pędu pszenicy jarej odmiany Nawra wykonano w oparciu o doświadczenie wazonowe przeprowadzone w szklarni, w 4 seriach. Ocenę zdrowotności przeprowadzono po 6 tygodniach od siewu pszenicy. Stwierdzono korzystny wpływ międzyplonów ścierniskowych na występowanie chorób podsuszkowych pszenicy. Po wszystkich badanych roślinach bobowatych następował spadek porażenia podstawy pędu przez Fusarium spp. Uprawa pszenicy po seradeli umożliwiła również polepszenie zdrowotności korzeni. Rodzaj przyoranej biomasy wpływał niejednoznacznie na zdrowotność pszenicy. Z korzeni z nekrozami izolowano głównie Gaeumannomyces graminis, rzadziej Fusarium spp., Rhizoctonia spp. i Cochliobolus sativus. Ze źdźbeł uzyskiwano najczęściej Fusarium culmorum, Fusarium oxysporum i C. sativus. Znacznie mniej uzyskano innych grzybów rodzaju Fusarium, Rhizoctonia i G. graminis.

Słowa kluczowe: międzyplon ścierniskowy; pszenica jara; korzenie; podstawa pędu; choroby; grzyby

\footnotetext{
Uniwersytet Technologiczno-Przyrodniczy im. Jana i Jędrzeja Śniadeckich w Bydgoszczy

Kordeckiego 20, 85-225 Bydgoszcz

${ }^{1}$ Zakład Fitopatologii Molekularnej

${ }^{2}$ Katedra Agrotechnologii

${ }^{3}$ ProCam Polska, Nowy Świat 42/44, 80-299 Gdańsk

*corresponding author: grzegorz.lemanczyk@utp.edu.pl
} 


\section{Wstęp / Introduction}

W Polsce coraz bardziej powszechne stają się ograniczenia w stosowaniu zabiegów agrotechnicznych. Niejednokrotnie sieje się zboża po zbożach (Cacak-Pietrzak i wsp. 2014). Jednak takie postępowanie wiąże się z ryzykiem uzyskania niższych plonów o obniżonej jakości ziarna. Duży udział zbóż w zmianowaniu prowadzi do jednostronnego wyczerpania gleby ze składników odżywczych, a także nagromadzenia w glebie niektórych agrofagów (Jaskulska i Jaskulski 2011; Lemańczyk i Wilczewski 2014). Uprawa zbóż po sobie zwiększa ryzyko porażenia przez patogeny atakujące korzenie i podstawę źdźbła (Lemańczyk i Wilczewski 2008).

Jednym ze sposobów złagodzenia negatywnych skutków uprawy zbóż po sobie jest wprowadzenie do uprawy międzyplonów ścierniskowych. Dzięki nim następuje zwiększenie bioróżnorodności agroekosystemów (Wilczewski i wsp. 2014). Międzyplony ścierniskowe istotnie wpływają na warunki glebowe, szczególnie gdy uprawiane są $\mathrm{z}$ przeznaczeniem na zielony nawóz (Wilczewski i Skinder 2011). Ich wprowadzenie do gleby skutkuje zwiększeniem zawartości mikrobiologicznej biomasy glebowej, a także jej aktywności enzymatycznej (Piotrowska-Długosz i Wilczewski 2014). W efekcie następuje wzrost plonów, poprawa wartości elementów strukturalnych plonowania oraz zwiększenie koncentracji składników mineralnych w ziarnie zbóż uprawianych po międzyplonie ścierniskowym (Wilczewski i wsp. 2014). Zmiany te wynikają również $\mathrm{z}$ istotnego wpływu tych upraw w zakresie ograniczenia występowania chorób (Kraska i Mielniczuk 2012). Warunkiem pozytywnego wpływu na zdrowotność roślin i cechy jakościowe ziarna jest właściwy dobór roślin uprawianych w międzyplonie ścierniskowym oraz odpowiednia ilość wniesionej do gleby biomasy, której mineralizacja trwa do czasu formowania ziarna rośliny (Wilczewski i Skinder 2011). Głównie rośliny kapustowate wskazuje się jako te, które zmniejszają stopień porażenia patogenami zbóż uprawianych $\mathrm{w}$ monokulturze. Znaczenie mogą mieć również rośliny bobowate (Lemańczyk i Wilczewski 2014).

Celem przeprowadzonych badań było określenie wpływu rodzaju biomasy różnych gatunków roślin bobowatych uprawianych w międzyplonie ścierniskowym po jęczmieniu jarym na zdrowotność korzeni i podstawy pędu pszenicy jarej.

\section{Materiały i metody / Materials and methods}

Badania wykonano jako doświadczenie wazonowe, przeprowadzone w szklarni, w 4 seriach, w oparciu o ścisłe doświadczenie polowe. Glebę do wazonów pobierano z poletek doświadczeń polowych prowadzonych na glebie płowej, wytworzonej z piasku gliniastego mocnego, kompleksu żytniego bardzo dobrego. Czynnikami doświadczenia były: rodzaj przyoranej biomasy (biomasa części podziemnych i nadziemnych; biomasa resztek pozbiorowych) oraz gatunek roślin bobowatych uprawianych w międzyplonie ścierniskowym (seradela siewna, groch siewny, łubin żółty, kontrola - bez międzyplonu).
Wiosną, bezpośrednio przed siewem pszenicy jarej, z poletek na których prowadzono doświadczenie polowe, z warstwy ornej pobierano ziemię do plastikowych doniczek $(15 \times 15 \times 15 \mathrm{~cm})$, w których następnie wysiewano po 20 odkażonych, niezaprawionych ziaren pszenicy jarej odmiany Nawra. Przed napełnieniem doniczek wilgotność ziemi ustalono na poziomie 40\% całkowitej pojemności wodnej (CPW). Następnie wysiewano pszenicę i uzupełniano wilgotność do $60 \%$ CPW i na tym poziomie utrzymywano ją przez cały okres uprawy. Przez cały czas doświadczenie prowadzono w takich samych warunkach, w następującym cyklu: 16 godzin na świetle, w temperaturze $20-21^{\circ} \mathrm{C}$ oraz 8 godzin w ciemności, w temperaturze $18-19^{\circ} \mathrm{C}$.

Obserwacje zdrowotności przeprowadzono po 6 tygodniach od wysiewu ziaren pszenicy. W warunkach laboratoryjnych, po umyciu korzeni, oceniano nasilenie objawów chorobowych na korzeniach powodowanych przez kompleks patogenów oraz podstawie pędu spowodowanych przez Fusarium spp. (fuzaryjna zgorzel podstawy źdźbła i korzeni), Oculimacula spp. (łamliwość źdźbła zbóż) i Rhizoctonia spp. (ostra plamistość oczkowa) w skali $0-4^{\circ}$. Na podstawie oceny wyrażonej w stopniach obliczano indeks chorobowy według wzoru Townsenda i Heubergera (1943). Uzyskane wyniki poddano weryfikacji statystycznej, a istotność różnic określono przy użyciu półprzedziału ufności Tukeya, dla poziomu istotności $\mathrm{P}=0,05$. Zastosowano metodę dwuczynnikowej analizy wariancji, dla modelu całkowicie losowego, przeprowadzonego w 4 seriach, 5 powtórzeniach. Każde powtórzenie składało się z 1 doniczki z 20 roślinami. Zamieszczone w pracy wyniki stanowią średnią z 4 lat badań.

Ocenę zdrowotności uzupełniono analizą mikologiczną. Materiał do izolacji grzybów pobierano losowo $\mathrm{Z}$ korzeni i podstaw pędów wykazujących zmiany chorobowe. Wycinano po 100 fragmentów o długości $5 \mathrm{~mm}, \mathrm{z}$ pogranicza tkanki zdrowej i chorej. Materiał ten płukano przez 45 minut pod bieżąca wodą, odkażano przez 20 sekund w $1 \% \mathrm{AgNO}_{3}$, a następnie płukano trzykrotnie po 1 minucie w destylowanej sterylnej wodzie i po 6 skrawków wykładano na pożywkę PDA (Potato Dextrose Agar) ze streptomycyną na płytki Petriego. Wyrastające kolonie grzybów odszczepiano na skosy agarowe. Po doprowadzeniu kolonii grzybów do czystych kultur, przeszczepiano je na pożywkę PDA i SNA (Synthetic Nutrient Agar), a następnie przystąpiono do ich oznaczania na podstawie dostępnych kluczy mikologicznych i opracowań monograficznych (Gilman 1957; Booth 1971; Domsch i Gams 1972; Kwaśna i wsp. 1991).

Dla rozróżnienia wybranych gatunków grzybów obok tradycyjnych metod wykorzystano technikę PCR (polymerase chain reaction). W tym celu zastosowano startery SCAR (Sequence Characterized Amplified Region) specyficzne gatunkowo dla Fusarium culmorum (Nicholson i wsp. 1998), Fusarium poae (Parry i Nicholson 1996), Gaeumannomyces graminis (Fouly i Wilkinson 2000), Gibberella avenacea (anamorfa Fusarium avenaceum) (Turner i wsp. 1998), Oculimacula yallundae i Oculimacula acuformis (Nicholson i wsp. 1997), Rhizoctonia cerealis (Nicholson i Parry 1996), Rhizoctonia solani (Johanson i wsp. 1998). Izolację całkowitego DNA wykonano 
według zmodyfikowanej metody Doyle i Doyle (1990). Do przeprowadzenia reakcji PCR zastosowano zestaw Taq PCR Core Kit (QIAGEN Inc., USA).

\section{Wyniki i dyskusja / Results and discussion}

$\mathrm{Na}$ sześciotygodniowych roślinach pszenicy rosnącej w wazonach średnio dla czteroletnich badań obserwowano najwięcej objawów fuzaryjnej zgorzeli podstawy źdźbła i korzeni, następnie zgorzeli korzeni (tab. 1). Znacznie mniej było objawów łamliwości źdźbła zbóż, a ostrej plamistości oczkowej nie stwierdzono wcale, co mogło wynikać $\mathrm{z}$ wolnego wzrostu liniowego patogenów powodujących te choroby (Lemańczyk i Wilczewski 2014). Zazwyczaj ich objawy są widoczne w późniejszych fazach rozwojowych zbóż. Stosunkowo silne porażenie korzeni mogło być spowodowane tym, iż przedplonem był jęczmień, a przedprzedplonem pszenica ozima. Nasilenie obserwowanych chorób było jednak znacznie zróżnicowane $\mathrm{w}$ poszczególnych latach badań. Zgorzeli korzeni było najwięcej w trzecim roku badań, a fuzaryjnej zgorzeli podstawy źdźbła i korzeni oraz łamliwości źdźbła zbóż w pierwszym roku badań. Najsłabsze nasilenie zgorzeli korzeni stwierdzono w pierwszym roku badań, a fuzaryjnej zgorzeli podstawy źdźbła i korzeni oraz łamliwości źdźbła zbóż - w czwartym roku badań.

Podobnie, jak w badaniach Kraski i Mielniczuk (2012) oraz Lemańczyka i Wilczewskiego (2014) występowanie chorób podsuszkowych istotnie zależało od zastosowanego międzyplonu ścierniskowego oraz rodzaju przyoranej biomasy. Wprowadzenie międzyplonów ścierniskowych w znacznym stopniu łagodziło negatywne skutki niewłaściwego następstwa roślin. Zdrowotność korzeni i podstawy źdźbła pszenicy uprawianej w wazonach $\mathrm{w}$ glebie pochodzącej z poletek po bobowatych międzyplonach ścierniskowych była zróżnicowana. Zależała zarówno od gatunku rośliny uprawianej w międzyplonie, jak i rodzaju przyoranej biomasy tych roślin.

Nasilenie objawów fuzaryjnej zgorzeli podstawy źdźbła i korzeni na pszenicy rosnącej w wazonach wypełnionych ziemią pobraną $\mathrm{z}$ poletek, na których uprawiano międzyplony było istotnie mniejsze niż $\mathrm{w}$ wazonach kontrolnych, tj. bez międzyplonów (tab. 3). Najmniej objawów stwierdzono w kombinacji, gdzie międzyplonem był łubin, a istotnie więcej w kombinacji, gdzie międzyplonem była seradela, która przyczyniła się jednak do zmniejszenia nasilenia zgorzeli korzeni (tab. 2). Łamli- wości źdźbła zbóż było najmniej w kombinacji, gdzie międzyplonem była seradela, a najwięcej w kombinacji $\mathrm{z}$ grochem (tab. 4). Uzyskany w badaniach własnych na ogół korzystny wpływ międzyplonów z roślin bobowatych na porażenie podstawy źdźbła jest zgodny $\mathrm{z}$ wynikami wcześniejszych badań (Kraska i Mielniczuk 2012; Lemańczyk i Wilczewski 2014). Nasilenie objawów zgorzeli korzeni oraz fuzaryjnej zgorzeli podstawy źdźbła i korzeni było mniejsze na roślinach rosnących w wazonach zawierających ziemię $\mathrm{z}$ obiektów z przyoraną całą biomasą roślin uprawianych $\mathrm{w}$ międzyplonie niż $\mathrm{z}$ samymi resztkami pozbiorowymi. Spadek porażenia korzeni był szczególnie widoczny w przypadku seradeli i łubinu, a fuzaryjnej zgorzeli podstawy źdźbła i korzeni - po grochu. Przyoranie całej biomasy roślin powodowało jednak wzrost nasilenia łamliwości źdźbła zbóż, w obiektach po seradeli i grochu.

Z korzeni pszenicy z objawami zgorzeli izolowano najczęściej G. graminis, który stanowił 37,0\% (tab. 5). Potwierdza to wcześniejsze doniesienia, że patogen ten jest głównym sprawcą zgorzeli korzeni pszenicy ozimej, zwłaszcza uprawianej po pszenicy lub innych zbożach, z wyjątkiem owsa (Lemańczyk i Wilczewski 2008; Bockus i wsp. 2010). Pląskowska (2005) uzyskiwała go znacznie rzadziej, natomiast Kraska i Mielniczuk (2012) nie stwierdzili obecności tego grzyba na korzeniach pszenicy jarej. Autorzy ci znacznie częściej izolowali natomiast Fusarium spp., co thumaczą zdolnościami tych grzybów do saprotroficznego rozwoju $\mathrm{w}$ glebie, ich szybkim wzrostem oraz wytwarzaniem licznych zarodników. Z korzeni pszenicy szczególnie często izoluje się F.culmorum i G. avenacea (Pląskowska 2005; Kraska i Mielniczuk 2012). Również $\mathrm{w}$ badaniach własnych znaczną grupę stanowiły grzyby, które w stadium konidialnym zaliczane są do rodzaju Fusarium (17,6\%). Wśród nich dominowały: F. culmorum (4,1\%), Haematonectria haematococca (anamorfa Fusarium solani) (5,3\%) i Fusarium oxysporum $(4,9 \%)$. Spośród potencjalnych patogenów znacznie mniej izolowano Rhizoctonia spp. i Cochliobolus sativus. Znaczną część stanowiły grzyby saprotroficzne dla pszenicy.

Ze źdźbeł $\mathrm{z}$ objawami chorobowymi najczęściej izolowano F. culmorum, F. oxysporum i C. sativus. Ich udział wynosił odpowiednio 18,$2 ; 11,0$ i $25,8 \%$ (tab. 5). Znacznie mniej uzyskano innych gatunków rodzaju Fusarium, Rhizoctonia spp. i G. graminis. Również inni autorzy z podstawy źdźbeł pszenicy jarej wykazującej zmiany chorobowe najczęściej izolowali grzyby rodzaju Fusarium, bez względu na rodzaj zastosowanego

Tabela 1. Nasilenie chorób na korzeniach i podstawie pędu pszenicy w poszczególnych latach badania - indeks chorobowy [\%] Table 1. The severity of disease on wheat roots and stem bases in individual years of study - disease index [\%]

\begin{tabular}{l|r|r|c|c|c}
\hline \multicolumn{1}{c|}{$\begin{array}{c}\text { Choroba } \\
\text { Disease }\end{array}$} & \multicolumn{5}{c}{ Rok badań - Year of study } \\
\cline { 2 - 7 } & $\begin{array}{c}\text { 1. rok } \\
\text { 1st year }\end{array}$ & $\begin{array}{c}\text { 2. rok } \\
\text { 2nd year }\end{array}$ & $\begin{array}{c}\text { 3. rok } \\
\text { 3rd year }\end{array}$ & $\begin{array}{c}4 \text {. rok } \\
\text { 4th year }\end{array}$ & $\begin{array}{c}\text { średnio } \\
\text { mean }\end{array}$ \\
\hline Zgorzel korzeni - Root rot & $2,74 \mathrm{a}$ & $14,84 \mathrm{c}$ & $18,97 \mathrm{~d}$ & $6,03 \mathrm{~b}$ & 10,65 \\
\hline Fuzaryjna zgorzel podstawy źdźbła i korzeni - Fusarium foot rot & $18,29 \mathrm{c}$ & $12,04 \mathrm{~b}$ & $13,68 \mathrm{~b}$ & $7,38 \mathrm{a}$ & 12,85 \\
\hline Lamliwość źdźbła zbóż - Eyespot & $9,14 \mathrm{c}$ & $2,17 \mathrm{ab}$ & $4,09 \mathrm{~b}$ & $0,12 \mathrm{a}$ & 3,88 \\
\hline
\end{tabular}

Wartości w wierszach oznaczone różnymi literami różnią się od siebie istotnie przy $\mathrm{P}=0,05$ - Values in the same line followed by different letters differed significantly at $\mathrm{P}=0.05$ 
Tabela 2. Wpływ roślin bobowatych i rodzaju przyoranej biomasy na zdrowotność korzeni - indeks chorobowy [\%]; średnie z czterech lat badań

Table 2. Effect of legume plants and type of ploughed-in biomass on the health status of roots - disease index [\%]; means for four years

\begin{tabular}{l|c|c|c|c|c}
\hline \multirow{2}{*}{$\begin{array}{c}\text { Rodzaj przyoranej biomasy } \\
\text { Type of ploughed-in biomass }\end{array}$} & $\begin{array}{c}\text { Międzyplon - Catch crop } \\
\text { seradela siewna } \\
\text { serradella }\end{array}$ & $\begin{array}{c}\text { groch siewny } \\
\text { field pea }\end{array}$ & $\begin{array}{c}\text { tubin żółty } \\
\text { yellow lupine }\end{array}$ & $\begin{array}{c}\text { bez międzyplonu } \\
\text { without catch crop }\end{array}$ & $\begin{array}{c}\text { średnio } \\
\text { mean }\end{array}$ \\
\hline PN & $7,7 \mathrm{Aa}$ & $11,0 \mathrm{~b}$ & $9,6 \mathrm{Aab}$ & $11,0 \mathrm{~b}$ & $9,83 \mathrm{~A}$ \\
\hline $\mathrm{P}$ & $10,2 \mathrm{~B}$ & 12,1 & $12,7 \mathrm{~B}$ & 10,9 & $11,48 \mathrm{~B}$ \\
\hline Średnio - Mean & $8,95 \mathrm{a}$ & $11,55 \mathrm{~b}$ & $11,15 \mathrm{~b}$ & $10,95 \mathrm{~b}$ & 10,65 \\
\hline
\end{tabular}

PN - biomasa części podziemnych i nadziemnych - biomass of underground and aboveground parts

$\mathrm{P}$ - biomasa resztek pozbiorowych - post-harvest residue biomass

Wartości oznaczone różnymi literami różnią się od siebie istotnie przy $\mathrm{P}=0,05$ (duże litery oznaczają istotny wpływ rodzaju przyoranej biomasy porównanie w pionie, małe istotny wpływ międzyplonu - porównanie w poziomie) - Means followed by different letters differed significantly at $\mathrm{P}=0.05$ (capital letters indicate a significant effect of type of ploughed-in biomass - comparing vertical, lower-case letters indicate a significant effect of catch crop - comparing horizontal)

Tabela 3. Wpływ roślin bobowatych i rodzaju przyoranej biomasy na występowanie fuzaryjnej zgorzeli podstawy źdźbła i korzeni - indeks chorobowy [\%]; średnie z czterech lat badań

Table 3. Effect of legume plants and type of ploughed-in biomass on the occurrence of Fusarium foot rot - disease index [\%]; means for four years

Rodzaj przyoranej biomasy

Type of ploughed-in biomass

\begin{tabular}{|c|c|c|c|c|c|}
\hline & serradella & 11eld pea & yellow lupine & without catch crop & mean \\
\hline $\mathrm{PN}$ & $12,8 \mathrm{~b}$ & $11,2 \mathrm{Aa}$ & $10,7 \mathrm{a}$ & $15,5 \mathrm{c}$ & $12,55 \mathrm{~A}$ \\
\hline $\mathrm{P}$ & 12,3 & $12,7 \mathrm{~B}$ & 11,7 & 15,9 & $13,15 \mathrm{~B}$ \\
\hline Średnio - Mean & $12,55 \mathrm{~b}$ & $11,95 \mathrm{ab}$ & $11,20 \mathrm{a}$ & $15,70 \mathrm{c}$ & 12,85 \\
\hline
\end{tabular}

$\mathrm{PN}$ - biomasa części podziemnych i nadziemnych - biomass of underground and aboveground parts

$\mathrm{P}$ - biomasa resztek pozbiorowych - post-harvest residue biomass

Wartości oznaczone różnymi literami różnią się od siebie istotnie przy $\mathrm{P}=0,05$ (duże litery oznaczaja istotny wpływ rodzaju przyoranej biomasy porównanie w pionie, małe istotny wpływ międzyplonu - porównanie w poziomie) - Means followed by different letters differed significantly at $\mathrm{P}=0.05$ (capital letters indicate a significant effect of type of ploughed-in biomass - comparing vertical, lower-case letters indicate a significant effect of catch crop - comparing horizontal)

Tabela 4. Wpływ roślin bobowatych i rodzaju przyoranej biomasy na występowanie łamliwości źdźbła zbóż - indeks chorobowy [\%]; średnie z czterech lat badań

Table 4. Effect of legume plants and type of ploughed-in biomass on the occurrence of eyespot - disease index [\%]; means for four years

Rodzaj przyoranej biomasy

Type of ploughed-in biomass

\begin{tabular}{l|c|c|c|c|c} 
& serradella & field pea & yellow lupine & without catch crop & mean \\
\hline PN & $4,0 \mathrm{Ba}$ & $4,9 \mathrm{Bb}$ & $3,9 \mathrm{a}$ & $3,9 \mathrm{a}$ & $4,18 \mathrm{~B}$ \\
\hline $\mathrm{N}$ & $3,2 \mathrm{~A}$ & $3,6 \mathrm{~A}$ & 3,8 & 3,7 & $3,58 \mathrm{~A}$ \\
\hline Średnio - Mean & $3,60 \mathrm{a}$ & $4,25 \mathrm{~b}$ & $3,85 \mathrm{ab}$ & $3,80 \mathrm{ab}$ & 3,88 \\
\hline
\end{tabular}

PN - biomasa części podziemnych i nadziemnych - biomass of underground and aboveground parts

$\mathrm{P}$ - biomasa resztek pozbiorowych - post-harvest residue biomass

Wartości oznaczone różnymi literami różnią się od siebie istotnie przy $\mathrm{P}=0,05$ (duże litery oznaczają istotny wpływ rodzaju przyoranej biomasy - porównanie w pionie, małe istotny wpływ międzyplonu - porównanie w poziomie) - Means followed by different letters differed significantly at $\mathrm{P}=0.05$ (capital letters indicate a significant effect of type of ploughed-in biomass - comparing vertical, lower-case letters indicate a significant effect of catch crop - comparing horizontal)

międzyplonu (Windels i Wiersma 1992; Kraska i Mielniczuk 2012). Często za sprawcę porażenia podstawy źdźbła uważa się F. culmorum (Pląskowska 2005; Kraska i Mielniczuk 2012). Duży udział C. sativus na podstawie pędu mógł wynikać $\mathrm{z}$ faktu, iż doświadczenia prowadzono w szklarni, w której panowała wyższa temperatura niż w doświadczeniach polowych. Niewątpliwie takie warunki bardziej sprzyjają rozwojowi tego patogena, na co wskazuje Kosiada (2013). Mały udział $R$. cerealis oraz brak Oculimacula spp. mógł wynikać $\mathrm{z}$ wolnego wzrostu liniowego grzybni tych patogenów (Lemańczyk i Wilczewski 2014). Prawdopodobnie nie zdążyły one porazić tkanek pszenicy w silniejszym stopniu. 
Tabela 5. Grzyby występujące na korzeniach i podstawie pędu pszenicy z objawami chorobowymi

Table 5. Fungi occurring on wheat roots and stem bases with disease symptoms

\begin{tabular}{|c|c|c|}
\hline $\begin{array}{l}\text { Takson } \\
\text { Taxon }\end{array}$ & $\begin{array}{l}\text { Korzenie } \\
\text { Roots }\end{array}$ & $\begin{array}{c}\text { Podstawa pędu } \\
\text { Stem base }\end{array}$ \\
\hline Alternaria alternata (Fries.) Keiss. & $1,6^{1}(4)^{2}$ & - \\
\hline Aspergillus niger van Tieghen & $0,8(2)$ & - \\
\hline Chaetomium spp. & $3,7(9)$ & - \\
\hline Clonostachys rosea (Link) Schroers, Samuels, Seifert \& W. Gams & $12,8(31)$ & $7,6(16)$ \\
\hline Cochliobolus sativus (S. Ito \& Kurib.) Drechsler ex Dastur & $1,2(3)$ & $25,8(54)$ \\
\hline Fusarium culmorum (W.G. Smith) Sacc.* & $4,1(10)$ & $18,2(38)$ \\
\hline Fusarium oxysporum Schlecht. & $4,9(12)$ & $11,0(23)$ \\
\hline Fusarium poae (Peck.) Wollenw.* & - & $0,5(1)$ \\
\hline Gaeumannomyces graminis (Sacc.) Arx et Olivier* & $37,0(90)$ & - \\
\hline Gibberella avenacea R.J. Cook* & $0,8(2)$ & $1,4(3)$ \\
\hline Gibberella intricans Wollenw. & $2,5(6)$ & $5,7(12$ \\
\hline Haematonectria haematococca (Berk. \& Broome) Samuels \& Rossman & $5,3(13)$ & - \\
\hline Microdochium bolleyi (R. Sprague) de Hoog \& Herm.-Nijh. & $0,4(1)$ & $1,0(2)$ \\
\hline Mucor spp. & $1,6(4)$ & $2,4(5)$ \\
\hline Paecilomyces lilacinus (Thom) Samson & $2,0(5)$ & - \\
\hline Penicillium spp. & $6,6(16)$ & $3,3(7)$ \\
\hline Rhizoctonia cerealis van der Hoeven* & - & $1,9(4)$ \\
\hline Rhizoctonia solani Kühn* & $1,2(3)$ & $1,0(2)$ \\
\hline Trichoderma koningii Oud. & $1,2(3)$ & $4,8(10)$ \\
\hline Trichoderma polysporum (Link ex Pers.) Rifai & $3,3(8)$ & $1,0(2)$ \\
\hline Trichoderma virens (J.H. Mill., Giddens \& A.A. Foster) Arx & - & $0,5(1)$ \\
\hline Trichoderma viride Pers. ex Gray & $6,1(15)$ & $4,3(9)$ \\
\hline Umbelopsis vinacea (Dixon-Stew.) Arx & $0,4(1)$ & - \\
\hline Kolonie niezarodnikujące - Non-sporulating mycelia & $2,5(6)$ & $9,6(20)$ \\
\hline Łączna liczba izolatów - Total number of isolates & 244 & 209 \\
\hline
\end{tabular}

${ }^{1}$ procentowy udział grzybów - percentage share of fungi

${ }^{2} \mathrm{~W}$ nawiasach liczba uzyskanych izolatów - in brackets number of isolates

*przynależność gatunkowa potwierdzona techniką PCR przy użyciu gatunkowo specyficznych starterów SCAR - the taxonomy of species was confirmed by applying the PCR method using species-specific SCAR primers

\section{Wnioski / Conclusions}

1. Wykazano, iż uprawa międzyplonów ścierniskowych poprawia stan fitosanitarny stanowiska $z$ dużym udziałem zbóż w płodozmianie. Na polepszenie zdrowotności korzeni pszenicy korzystnie wpływała jej uprawa po seradeli. Po roślinach bobowatych następował również spadek porażenia podstawy pędu przez Fusarium spp.

2. Pozytywny wpływ przyoranej biomasy roślin uwidocznił się w poprawie zdrowotności pszenicy jarej. Na ogół korzystny wpływ międzyplonów był szczególnie silny, gdy jako zielony nawóz wykorzystywano całą wytworzoną biomasę.

3. Głównym sprawcą zgorzeli korzeni pszenicy był G. graminis, mniejsze znaczenie miały Fusarium spp., Rhizoctonia spp. i C. sativus. Objawy chorobowe występujące na podstawie pędu powodowane były głównie przez $F$. culmorum, $F$. oxysporum i $C$. sativus. Znacznie mniejszy udział miały inne gatunki Fusarium, Rhizoctonia spp. i G. graminis.

\section{Literatura / References}

Bockus W.W., Bowden R.L., Hunger R.M., Morrill W.L., Murray T.D., Smiley R.W. (eds.). 2010. Compendium of Wheat Diseases and Pests. 3-rd ed. APS Press, St. Paul, MN, 171 pp.

Booth T.C. 1971. The Genus Fusarium. Commonwealth Mycological Institute, Kew, Surrey, England, 237 pp.

Cacak-Pietrzak G., Ceglińska A., Jończyk K. 2014. Wartość wypiekowa mąki z ziarna odmian pszenicy uprawianych w ekologicznym systemie produkcji. [Value of baking flour wheat variety with grain grown the organic system of production]. Zeszyty Problemowe Postępów Nauk Rolniczych 576: 23-32. 
Domsch K.H., Gams W. 1972. Fungi in Agricultural Soils. Longman, London, 304 pp.

Doyle J.J., Doyle J.L. 1990. Isolation of plant DNA from fresh tissue. Focus 12 (1): 13-15.

Fouly H.M., Wilkinson H.T. 2000. Detection of Gaeumannomyces graminis varieties using polymerase chain reaction with varietyspecific primers. Plant Disease 84 (9): 947-951.

Gilman J.C. 1957. A Manual of Soil Fungi. Iowa State University Press, 450 pp.

Jaskulska I., Jaskulski D. 2011. Plony zbóż pastewnych i wyrównanie ziarna pszenicy chlebowej w zależności od warunków glebowych kształtowanych przez wieloletnie zróżnicowane nawożenie. [Yield of fodder cereals and uniformity of bread wheat grain depending on the soil conditions formed by long-term varied fertilization]. Zeszyty Problemowe Postępów Nauk Rolniczych 565: 99-107.

Johanson A., Turner H.C., McKay G.J., Brown A.E. 1998. A PCR-based method to distinguish fungi of the rice sheath-blight complex, Rhizoctonia solani, R. oryzae and $R$. oryzae-sativae. FEMS Microbiology Letters 162 (2): 289-294.

Kosiada T. 2013. Charakterystyka populacji Cochliobolus sativus (S. Ito \& Kurib.) Drechsler ex Dastur występującej w Wielkopolsce i na Kujawach. Bogucki, Wydawnictwo Naukowe, 90 ss.

Kraska P., Mielniczuk E. 2012. The occurrence of fungi on the stem base and roots of spring wheat (Triticum aestivum L.) grown in monoculture depending on tillage systems and catch crops. Acta Agrobotanica 65 (1): 79-90.

Kwaśna H., Chełkowski J., Zajkowski P. 1991. Fusarium. Flora polska. Grzyby (Mycota). Tom XXII. Instytut Botaniki PAN, Warszawa-Kraków, 138 ss.

Lemańczyk G., Wilczewski E. 2008. Wpływ roślin motylkowatych uprawianych w międzyplonie ścierniskowym na zdrowotność korzeni pszenicy jarej. [Impact of papilionaceous plants grown in stubble intercrop on the health status of spring wheat roots]. Zeszyty Problemowe Postepów Nauk Rolniczych 531: 113-123.

Lemańczyk G., Wilczewski E. 2014. Health status of spring barley grown on Alfisol as affected by catch crop. American Journal of Experimental Agriculture 4 (12): 1731-1742.

Nicholson P., Parry D.W. 1996. Development and use of a PCR assay to detect Rhizoctonia cerealis, the cause of sharp eyespot in wheat. Plant Pathology 45 (5): 872-883.

Nicholson P., Rezanoor H.N., Simpson D.R., Joyce D. 1997. Differentiation and quantification of the cereal eyespot fungi Tapesia yallundae and Tapesia acuformis using a PCR assay. Plant Pathology 46 (6): 842-856.

Nicholson P., Simpson D.R., Weston G., Rezanoor H.N., Lees A.K., Parry D., Joyce D. 1998. Detection and quantification of Fusarium culmorum and Fusarium graminearum in cereals using PCR assays. Physiological and Molecular Plant Pathology 53 (1): 17-37.

Parry D.W., Nicholson P. 1996. Development of a PCR assay to detect Fusarium poae in wheat. Plant Pathology 45 (2): 383-391.

Piotrowska-Długosz A., Wilczewski E. 2014. Assessment of soil nitrogen and related enzymes as influenced by the incorporation time of field pea cultivated as a catch crop in Alfisol. Environmental Monitoring and Assessment 186: 8425-8441.

Pląskowska E. 2005. Zdrowotność pszenicy jarej uprawianej w siewie czystym i w mieszaninach odmian. Zeszyty Naukowe Akademii Rolniczej we Wrocławiu, Rozprawy CCXXXVI, Rolnictwo, 528, 142 ss.

Townsend G.R., Heuberger J.W. 1943. Methods for estimating losses caused by diseases in fungicide experiments. Plant Disease Report 27 (17): 340-343.

Turner A.S., Lees A.K., Rezanoor H.N., Nicholson P. 1998. Refinement of PCR-detection of Fusarium avenaceum and evidence from DNA marker studies for phylogenetic relatedness to Fusarium tricinctum. Plant Pathology 47 (3): 278-288.

Wilczewski E., Skinder Z. 2011. Wartość przedplonowa roślin niemotylkowatych uprawianych w międzyplonie ścierniskowym dla pszenicy jarej. Cz. II. Zawartość ważniejszych makroskładników w ziarnie i słomie. [Previous crop value of non-legumes grown in stubble catch crop for spring wheat. Part II. Content of major macronutrients in grain and straw]. Fragmenta Agronomica 28 (1): $107-114$.

Wilczewski E., Piotrowska-Długosz A., Lemańczyk G. 2014. Influence of catch crop on soil properties and yield of spring barley. International Journal of Plant Production 8 (3): 391-407.

Windels C.E., Wiersma J.V. 1992. Incidens of Bipolaris and Fusarium on subcrown internodes of spring barley and wheat grown in continuous conservation tillage. Phytopathology 82 (6): 699-705. 